\title{
Achieving a Voice and Institutionalizing a Vision for Women: The Barnard Deanship at Columbia University, 1889-1947
}

\author{
Andrea Walton
}

What is a dean of women?... While a dean of women must be a woman's woman, under present conditions the position is determined by men as presidents of colleges and as boards of control. Must a dean be a learned woman who represents the best in higher education and ranks high in her chosen field? Should she be a society woman in the best sense of the term...A woman with human sympathy, who will win her girls? A physical director...An administrator? A dragon? A policewoman? Are deans like poets or can they be made? ${ }^{1}$

These questions concerning the nature of female leadership in higher education are central to the new scholarship on deans of women in the United States. This scholarship has shown that the hiring of deans of women and the development of the position and its responsibilities were most closely associated with two phenomena, the trend toward co-education and the rising female enrolments at colleges and universities. ${ }^{2}$ An important addition to

1. Mary P. Putnam, The Nation 98 (1 Jan. 1914): 10. Putnam's letter appeared at a time when the role and responsibilities of deans were becoming defined and the position was gaining national prominence. For this early period, see Lois Kimball Mathews, The Dean of Women (Boston: Houghton Mifflin, 1915). A point of clarification is in order: Mary P. Putnam was not related to either Dean Emily James Putnam, who will be discussed later in this essay, or Mary Putnam Jacobi, a well-known advocate of women's higher education in the U.S.

2. For the rise of female enrolments from 21 per cent in 1870 to 47.3 per cent in 1920 and for the trend toward co-education, see Barbara Solomon, In the Company of Educated Women (New Haven: Yale University Press, 1985), 44 (table 1), 58, 63 (table 2). For definitive works on the professionalization of the woman's deanship, see Robert A. Schwartz, "Reconceptualizing the Leadership Roles of Women in Higher Education: A Brief History on the Importance of Deans of Women,” Journal of Higher Education 68 (Sept./Oct. 1997): 502-23; Jana Nidiffer, Pioneering Deans of Women: More than Wise and Pious Matrons (New York City: Teachers' College Press, 2000); and Carolyn Terry Bashaw, "Stalwart Women": A Historical Analysis of Deans of Women in the South (New York: Teachers' College Press, 1999). For general works on lives of women deans who advanced women's status on co-educational campuses, see Rosalind Rosenberg, Beyond Separate Spheres: The Intellectual Roots of Modern Feminism (New Haven: 
our understanding of the ways gender influenced opportunities for women faculty, students, and administrators, these studies of deans of women on campuses in the U.S. have focused attention on a noteworthy career path for women that has been relatively unexplored by historians. ${ }^{3}$ Not surprisingly, most scholarship on deans has focused on the women who pioneered the deanship at fully co-educational institutions, where most women entering college after the 1870s studied and where the gender biases and inequalities on campus were substantial. Having both a personal understanding of women's situation in academic life and a platform for educating faculty men and trustees, female deans were often women's most vocal and effective advocates on co-educational campuses. Further, through their numbers and networks these female deans in co-educational institutions played a crucial role in developing the deanship as a professional option for women. ${ }^{4}$

In addition to these deans of women who crafted their careers at fully co-educational institutions, the history of women's higher education in the U.S. has produced two other types of women educational leaders: women who served in the capacity of president or dean at independent women's colleges - the likes of Smith, Wellesley, and Vassar ${ }^{5}$-and at co-ordinate women's colleges

Yale University Press, 1982), Part I; Karen Anderson, "Brick Bat and Roses: Lucy Diggs Slowe, 1883-1937,” in Lone Voyagers: Academic Women in Coeducational Institutions, 1870-1937, ed. Geraldine Joncich Clifford (New York City: Feminist Press, 1989), 283307; Lynn D. Gordon, Gender and Higher Education in the Progressive Era (New Haven: Yale University Press, 1990), 6-68, 92-9; and Joyce Antler, Lucy Sprague Mitchell: The Making of a Modern Woman (New Haven: Yale University Press, 1987).

3. For an argument that scholars of women's education in the U.S. have discounted the position of dean of women as marginalized and historically insignificant, see Bashaw, Stalwart Women, 2. For a brief discussion of the ways histories of women deans can dispel the stereotypes of the female dean as a "curmudgeon or housemother," see Nidiffer, Pioneering Deans, 2.

4. Marion Talbot, dean of women at the University of Chicago (1892-1925), organized the first meeting of deans in 1902. The emergent professional status of the female deanship was reflected by Columbia University's Teachers' College decision in 1914 to introduce a professional diploma covering the administrative skills needed for a deanship and by the founding of the National Association of Deans of Women in 1916. For a discussion of this push toward professionalization, see Nidiffer, Pioneering Deans, esp. 1-14, 72-6, 126-31.

5. Though the contributions of the independent women's colleges, particularly the oldest and commonly thought to be the most prestigious institutions, have been well represented in the secondary literature on women in education, critical studies of leadership at these women's colleges are just emerging. To date, such studies have focused on the presidency and faculty. See Patricia Ann Palmieri, In Adamless Eden: The Community of Faculty Women at Wellesley (New Haven: Yale University Press, 1995); Ruth Bordin, 
located within male-dominated universities such as Columbia's Barnard, Harvard's Radcliffe, and Brown's Women's College (later Pembroke). ${ }^{6}$ This paper will focus on this last type-deans in a coordinate setting-because they have been understudied and, moreover, because the challenges and possibilities of leadership in their institutional setting were unique. An institutional hybrid, female co-ordinate colleges within universities were founded as a solution to the "woman question" where co-education was staunchly resisted but the civic benefits of educating women were appreciated. In the U.S., female co-ordinates were founded in the East and the South, and were influenced by the example of the women's colleges at Oxford and Cambridge. The lack of research on the history of female co-ordinates and the variety of administrative arrangements that emerged on different campuses make any comparative study of co-ordinate colleges within the U.S.

Alice Freeman Palmer: The Evolution of a New Woman (Ann Arbor: University of Michigan Press, 1993); and Helen Lefkowitz Horowitz, The Power and Passion of M. Carey Thomas (New York: Alfred A. Knopf, 1994), and Alma Mater: Design and Experience in the Women's Colleges from Their Nineteenth-Century Beginnings to the 1930s (New York: Alfred A. Knopf, 1984). More research is needed to understand the variety of leadership positions at independent women's colleges, particularly when the presidency was held by a man and a second administrative position was held by a woman. Brief views of the decanal experience at a women's college may be gained from Barbara Miller Solomon, ed., The Evolution of an Educator: An Anthology of Published Writings of Ada Comstock (New York: Garland, 1987), 19-48 (formerly dean of women at the University of Minnesota, Comstock became the first dean at Smith College in 1912); and Andrea Walton, “'Scholar,' 'Lady,' 'Best Man in the English Department': Reconsidering the Career of Marjorie Hope Nicolson," History of Education Quarterly 40 (Summer 2000): 169-200 (Nicolson served as dean of Smith College under President William A. Neilson from 1923-1941, when she became the first woman to join the graduate faculty at Columbia University).

6. Perhaps even more so than the female administrators at the independent women's colleges, leaders at co-ordinate institutions have been under-studied. A notable exception is the discussion of the early female deans at Brown University's co-ordinate in Linda Eisenmann, “'Freedom to be Womanly': The Separate Culture of the Woman's College,” in The Search for Equity: Women at Brown University, 1891-1991, ed. Polly Welts Kaufman (Providence: Brown University Press, 1991), 55-87. For preliminary insights into the administration of the Harvard Annex, later Radcliffe College, see Sally Schwager, “"Harvard Women': A History of the Founding of Radcliffe College” (Ed.D. diss., Harvard University, 1982); and Dorothy Elia Howells, A Century to Celebrate: Radcliffe College, 1879-1979 (Cambridge: Radcliffe College, 1978). A brief view of the presidency of former schoolman Brandt Van Blarcom Dixon (1887-1919) at Sophie Newcomb, the female co-ordinate at Tulane University in New Orleans, is found in Gordon, Gender and Higher Education, 165-89. 
difficult. $^{7}$ For similar reasons, it lies outside the scope of this paper to draw on the experience of women's leadership in higher education outside the U.S., though an analysis comparing the U.S., Canada, and Britain, for example, would likely reveal significant parallels and influences. Rather, this study is limited to one national context, the United States, and aims to probe the deanship over time at one institutional setting - Barnard College at Columbia University.

I will consider the careers of four women who held the deanship at Barnard College from the co-ordinate college's founding in 1889 to the beginnings of the post-World War II era. During these decades, spanning Barnard's first half-century, Ella Weed (18891894), Emily James Smith (later Putnam, 1894-1900), Laura Drake Gill (1901-1907), and Virginia Gildersleeve (1911-1947) ledthe transformation of Barnard from a small local "experiment" designed to demonstrate women's intellectual talent into a leading women's college. In the process, these deans created a pattern of female leadership at Barnard that was distinctive among the cluster of northeastern women's colleges that would become the "pacesetters" in women's higher education-the Seven Sisters. ${ }^{8}$

As this paper will show, the different administrative styles and priorities the Barnard deans displayed were reflective of their personalities, their backgrounds, and the particular institutional circumstances they encountered. All four women hailed from white, middle-class or well-to-do eastern families that encouraged their daughters in pursuing higher education and in choosing an academic life. More important, in addition to these advantages of birth, Barnard's deans had the intellectual and social benefits of collegiate training at leading eastern women's colleges-Vassar, Bryn Mawr, Smith, and Barnard-and, with the exception of Ella Weed, the earliest incumbent, the cachet of a Ph.D.

A number of pioneering studies of women deans have used biography to focus on the tensions and consistency of an individual life and to illuminate the limits and possibilities of women's

7. For a general overview of women's opportunities at single-sex, co-ordinate, and coeducational institutions in the U.S., see Thomas Woody, A History of Women's Education in the United States (1929; reprint, New York: Octagon Books, 1974), II: 137-320.

8. Solomon, In the Company of Educated Women, 149. The Seven Sisters included: Vassar (1865), Wellesley (1875), Smith (1875), Mt. Holyoke (founded as a seminary in 1837/chartered as a college in 1888), Bryn Mawr (1885), Barnard (1889), and Radcliffe (founded as an annex in 1879/chartered as a college in 1894). The Seven Sisters are the all-female counterpart to the male colleges of the Ivy League. For a critical study of the Seven Sisters, see Horowitz, Alma Mater. 
leadership at male-dominated campuses. ${ }^{9}$ Other studies have used biographical portraits to depict emblematic "types" of female leaders or to exemplify the pivotal junctures in women's efforts to develop and professionalize the position of dean of women and the field of student personnel work. ${ }^{10}$ This study of Barnard's deans, informed by these earlier works, takes a different approach. It considers multiple lives to offer a sustained exploration of the intersection of these personalities with the history of Barnard College's development within the perimeter of the male-dominated Columbia University. The career stories that follow explore the vision, skill, and even foibles of Barnard's deans as they tried to achieve a voice for women at Barnard-Columbia and to shape their institution's identity vis-à-vis their male-dominated host university, on the one hand, and among peer institutions devoted to women's education, on the other.

\section{Ella Weed: Securing Equality for a Women's Co-ordinate Through Sameness}

Opened in 1889, Barnard, like many women's colleges in the eastern U.S., was founded because women were excluded from the region's oldest and most socially prestigious institutions. ${ }^{11}$ Adamant that co-education was "unnatural" and contrary to their institution's best interests, Columbia trustees rejected a number of petitions to admit women to Columbia College in the 1870s and 1880s. Eventually, though, Columbia trustees were swayed by growing public support for women's higher education in New York City, as well as by women's advances at Cambridge's Girton and Harvard's Radcliffe. ${ }^{12}$ In 1883, Columbia introduced an Oxbridgestyle examination system for women, the Collegiate Course. But

9. See Bashaw, Stalwart Women, and Anderson, “Brick Bat and Roses,” 283-307.

10. See Nidiffer, Pioneering Deans.

11. See Horowitz, Alma Mater,134-42; 237-61. Earlier “house histories” but nonetheless informative works on Barnard include Marian Churchill White, A History of Barnard College (New York: Columbia University Press, 1954), and Annie Nathan Meyer, Barnard Beginnings (Boston: Houghton Mifflin, 1935).

12. The achievements of Girton College (incorporated at Cambridge in 1873) and the Oxford women's colleges (Lady Margaret Hall and Somerville, founded in 1878 and 1879 respectively) were known to the New York City reformers who advocated the introduction of co-education at Columbia in the 1880s. See F.A.P. Barnard's annual reports dated 1879, 1880, and 1881 in The Rise of the University, ed. William F. Russell (New York: Columbia University Press, 1937), I: 249-83. 
women soon grew dissatisfied with the inadequacies of this provision, which allowed them to earn a coveted Columbia degree by examination but denied them lecture and library privileges. In 1888, Annie Nathan Meyer, a former Collegiate Course student, led an effort to remedy the educational situation for women in the city. Meyer and her supporters raised the funds to found a separate college for women, a female co-ordinate to stand alongside the allmale Columbia College, to be named after Columbia's late president, Frederick A.P. Barnard, who had been an eloquent albeit unsuccessful champion of full co-education at Columbia in the 1880s.

Lacking any substantial budget or endowment, the dedicated founders of this collegiate "experiment" looked to one of their own, Ella Weed, to oversee Barnard affairs. A founding trustee of Barnard and principal at Manhattan's Miss Annie Brown's School, Weed served as Barnard's de facto dean from the college's opening in 1889 to her death in 1894. Born in 1853, in the upstate New York town of Newburgh, Weed earned her bachelor's degree from Vassar College in 1873 and then taught school in Ohio before returning to the East and establishing her career in New York City. Weed agreed with Annie Nathan Meyer's criticisms of the Collegiate Course and had provided Meyer with advice and support in her fund-raising efforts. ${ }^{13}$ No less than Meyer, Weed was adamant that access to libraries and lectures was an integral part of collegiate studies and that only a full-fledged liberal arts education like the one men enjoyed at Columbia could demonstrate women's true intellectual talents and potential. "If a Columbia collegiate course for women, without resources, without foundation, could accomplish what a hundred and twenty-five years of wealth, power, organization, and instruction could do for young men, then a great college [like Columbia] was an absolute waste of labor and money," Weed wrote. ${ }^{14}$

But Weed and other supporters of Meyer's college-building campaign knew that founding an annex to stand as a counterpart to Columbia College required not only gaining the approval of

13. See Annette K. Baxter, Notable American Women, 1607-1950: A Biographical Dictionary, ed. Edward T. James, Janet Wilson James, and Paul S. Boyer (Cambridge: Harvard University Press, 1971), III: 556-7. For the text of Annie Nathan Meyer's 1888 letter to the Nation that led to the founding of Barnard College, see Meyer, Barnard Beginnings, 167-74.

14. Ella Weed, Report of Academic Committee (1890), in Quarter Century Report, Barnard College Archives, Barnard College, New York City (hereafter cited as BCA). 
Columbia's trustees but convincing New Yorkers to provide financial support for women's higher education. The college opened in 1889 with the pledges of 50 individuals who each promised 100 dollars for four years. The Barnard "experiment" that Weed oversaw, as an alumna historian later described, "started with nothing except the most irresistible and indestructible thing, an idea." 15

Though Barnard lacked an endowment, aspirations for the college were no less ambitious than had been the case at Vassar in 1865 and at Wellesley and Smith in 1875. The core idea that Barnard College hoped to institutionalize-“equal honors [the Columbia degree] for equal work" 16 - distinguished Barnard in the eyes of women educators, domestically and abroad, in ways even a substantial endowment could not. This may have caused some friction between Barnard and other all-female institutions. As one of Barnard's early supporters wrote: "To other annexes who sometimes accuse us of placing an undue value on the degree, we say, No, it is Oxford and Cambridge and Harvard who put the undue value on the degree when they refuse it to the students they have themselves educated...The degree is but the guinea's stamp...but in a world's market guineas are more convenient than nuggets."17 In Weed's eyes, Barnard was better situated than Cambridge's Girton or Harvard's Radcliffe, neither of which offered women the same degree as men. But, as Weed insightfully realized, Barnard's fate and fortunes were tied to a statusconscious men's college and to a rising university that feared feminization and therefore carefully delineated boundaries and expectations for women. Weed, and Barnard's future deans, had to work judiciously to enlarge opportunities for women within the ideology and legal framework of co-ordination.

The circumstances of Barnard's founding in light of Columbia's staunch resistance to co-education help explain the strict, rigorous tone that Weed cultivated when she welcomed Barnard's first 36 students (14 matriculants and 22 special students in science) to the brownstone that Annie Nathan Meyer had rented for classrooms at

15. Quoted in White, Barnard College, 3.

16. BCA, Ella Weed, Chair of Academic Committee, Meeting of Trustees and Associate Members, November 21, 1890, p. 13.

17. Fragment, BCA. Horowitz notes that "Barnard's beginnings initially made its acceptance problematic" to the established women's colleges and that relations among the women's colleges were "more competitive than cordial in the years before the Seven Sisters Conference.” See Horowitz, Alma Mater, xvi. 
363 Madison Avenue, only a few blocks away from Columbia, in mid-town Manhattan. Feeling the heavy burden of proving the efficacy of the Barnard "experiment" before the end of the college's four-year provisional charter from New York State, Weed worked to advance women's cause at Columbia through the principle of sameness and the strategy of subordination. ${ }^{18}$ Though the northeastern women's colleges did in fact offer models of innovative teaching, and even research, Barnard's primary frame of reference was local: its male host institution, Columbia. Weed enthusiastically embraced Columbia's notions of excellence and sought to create legitimacy for Barnard by observing strict conformity with Columbia College's entrance standards (including Greek, which was regarded as the litmus test of rigour), prescribed curriculum, examinations, and other educational aspects-even academic costume.

Weed's daily energies at Barnard were absorbed in arranging the timetable, advising students, and resolving unexpected problems. Charting the unknown terrain of Barnard-Columbia co-operation required diplomacy as she conferred with Columbia's dean and faculty, and with Barnard's Chairman of the Board, the Reverend Arthur Brooks. Weed was "the one and only really constructive and binding force” during Barnard's early years, one admiring Columbia administrator wrote. ${ }^{19}$ Part of Weed's ability to foster a sense of purposefulness and direction during Barnard's early years, involved cultivating Barnard's standing in the eyes of Columbia men and protecting Barnard's public image. Both were crucial to gaining the financial and ideological support for the young college. For this reason, Weed, like leaders at other women's colleges, followed a cautious path and took steps to shelter Barnard from the controversial issues of suffragism and feminism. In effect, she sought to depoliticize what was actually a radical endeavour in women's liberal arts education. "Barnard College is nothing so temporary and inutile as a mere cog in the wheel of feminist propaganda,” Ella Weed wrote in her annual report for $1890 .^{20}$

18. For a discussion of subordination as a strategy that women employed individually and collectively to seek advancement in male-dominated professions and areas of study, see Penina M. Glazer and Miriam Slater, Unequal Colleagues: The Entrance of Women into the Professions, 1890-1940 (New Brunswick: Rutgers University Press, 1987), 210, $213-$ 16, 231.

19. Columbia University Central Files, University Archives and Records, Columbia University, New York City (hereafter cited as CUCF), Nicholas Murray Butler to Virginia Gildersleeve, 16 Feb. 1934.

20. BCA, quoted in Quarter Century Report, 9. 


\section{If, Educationally, Barnard Is Columbia, Can Women Teach? The Female Professor as Anomaly}

As the politics of Weed's era made clear, there were decided benefits to Barnard's early relationship with Columbia University, and there were also trade-offs. Barnard's faculty was to be a Columbia-appointed faculty, and this inevitably meant a male faculty. There was a measure of irony, then, that the long-awaited liberal arts college for women in New York City by necessity excluded scholarly women from the types of faculty positions they might obtain elsewhere (in women's colleges, land-grant institutions, and more western regions of the U.S.).

Barnard's first female academic appointment in fact came in the College's second year, 1890. It was the result not of advocacy or enlightenment, but rather, a pragmatic solution to a staffing problem. On hearing that Barnard had a laboratory fully equipped with microscopes, but no Columbia instructor, Dr. Emily L. Gregory, a botanist who had training at Cornell and Zurich, offered to organize the Barnard department and to provide lectures without salary. But Gregory's generous offer nevertheless posed a dilemma for Barnard. Weed understood that the "intense and proper ambitions” of Seth Low, Columbia's president, made him dread "diverting interest and work away from the university." 21 Having Barnard's best interest in mind, she could not chance any public perception that Barnard was different from Columbia or trying to take a separate course. "I should be satisfied with almost anything which should stamp all instructors at Barnard as instructors attached to Columbia. The only strength of our position is that Barnard College is Columbia College," Weed wrote. ${ }^{22}$ Concerned about the value and standard of Columbia's degree, Low approved Gregory's appointment but underscored that this anomalous nonColumbia appointment was "an exception to be regretted, rather than precedent to be followed." 23

For her part, Gregory self-consciously fashioned her teaching duties at Barnard as a personal contribution to assuring the college's early success and, beyond that, promoting broader educational and professional opportunities for women in academe.

\footnotetext{
21. BCA, Ella Weed to Silas Brownell, 28 Oct. 1890. Weed often underscored the importance of Barnard's connection to Columbia. See BCA, Dean's Annual Report,1890, 8.

22. Emphasis added. BCA, Ella Weed to Silas Brownell, 28 Oct. 1890.

23. BCA, Seth Low to Emily James Smith, 17 Jan. 1895 and 10 Apr. 1897.
} 
Readily becoming a mentor to her botany assistants, she required them to work for a degree but understood the difficulties of combining time-consuming laboratory work and advanced studies. In her estimation, the doctorate and, hence, future academic opportunities seemed open only to rich women or to fortunate fellowship holders. "Men are helped with fellowships in order to get degrees why not women?” she wrote to Ella Weed in $1893 .{ }^{24}$ Weed was not insensitive to these issues, and, in fact, had already broached the issue with Seth Low, but was told to await a more auspicious time to push Columbia's trustees for broader opportunities for women in Columbia's newly founded graduate faculties. Unfortunately, Weed did not live to see women gain their entry to university-level courses. She died unexpectedly in 1894, leaving Barnard without the personality that had been so intimately intertwined with the daily life of the college since its opening.

\section{In Search of A Dean: What is a Dean?}

News of Weed's death was a deep psychological blow to Barnard trustees. In naming a new executive head, the college's trustees for the first time wrestled with articulating the qualities that Barnard needed in a leader and debated whether a woman or a man might best serve the college's students and interests. This crucial step would convey to Columbia and to the New York public — potential students and donors - the trustees' vision of the type of college Barnard aspired to be. At a time when not all the eastern women's colleges had a female head, Barnard's trustees, with Columbia president Low's full support, readily determined that Barnard College should have as its dean not a matron-like figure, but a college-educated woman of accomplishment. ${ }^{25}$

Searching for the "strongest woman in this country," 26 the trustees hoped to appoint an executive woman, a scholar whose feminine demeanour would effectively silence detractors who ridiculed educated women as mannish. The trustees' concern was not insignificant. Traditional notions of "femininity" and "masculinity" and a concern with protecting both the masculine ethos of intellectual life and the purity of womanly sensibilities had

24. BCA, Emily Gregory to Mrs. Bessie Helmer, 5 May 1893; and Emily Gregory to Miss Weed, 22 June 1893.

25. As president of Columbia University, Seth Low was also president of Barnard. 26. BCA, George Plimpton to Fred S. Wait, 7 Feb. 1894. 
figured prominently in Columbia's earlier rejection of coeducation. ${ }^{27}$ Gender ideology, as the careers of the deans illustrate, also shaped the expectations Columbia men held for Barnard College and the expectations that Barnard and Columbia trustees held for the woman occupying Barnard's deanship.

The pool of talented and experienced candidates from which Barnard, the youngest of the eastern Seven Sisters Colleges, might select a dean reflected the sizeable advances women had already achieved in higher education. Treasurer George Plimpton, not surprisingly, expressed great interest in recruiting Alice Longfellow, who had studied at Girton and, perhaps even more important, had a proven track record as a successful fund-raiser on behalf of Harvard's Radcliffe Annex (soon to be Radcliffe College). Former head of Columbia's School of Library Service, Melville Dewey, who had encountered substantial anti-female sentiment in trying to establish library work at Columbia, wrote enthusiastically on behalf of the first female recipient of a Columbia Ph.D., the mathematician Winifred Merrill Edgerton, as did her former professor, J.K. Rees, who argued that her scholastic performance demonstrated women's intellectual potential and hence influenced the decision of Columbia trustees to approve of co-ordinate education: "There would have been no Barnard had Winifred Edgerton not done the brilliant work she did in 1884-85 at the old college."28

\section{Emily James Putnam: A Scholar Steers Barnard's Course}

Because the most experienced women wanted to stay on at their respective institutions, the Barnard trustees looked for a woman who held great promise. The enthusiastic, if perhaps surprising,

\footnotetext{
27. The ideological resistance of the Columbia trustees to co-education is conveyed in CUCF, "Minutes of the University Trustees," 8 May 1883. Also see F.A.P. Barnard's annual reports dated 1879, 1880, and 1881 in The Rise of the University, ed. Russell, I: 249-83; and William Tenney Brewster, "Barnard College, 1889-1910," Columbia University Quarterly 12 (Mar. 1910): 153.

28. Edgerton's doctoral degree was earned through the Collegiate Course. BCA, Melville Dewey to Plimpton, 10 Feb. and 15 Mar. 1894; J.K. Rees to George Plimpton, 10 Mar. 1894. Other top names considered for the Barnard deanship included Mary Calkins, the Harvard-educated philosopher; Louise Brownell, Warden of Sage College (and daughter of trustee Silas Brownell); Margaret Washburn, the Columbia-educated psychologist; Lida Shaw King, dean at Women’s College, Brown University; and Marian Talbot, dean at the University of Chicago.
} 
choice of Barnard's trustees was twenty-nine-year-old Emily James Smith (later Putnam). ${ }^{29}$ When she was appointed in 1894, Putnam was not a well-known figure or proven administrator, but the trustees believed her limited supervisory experience was far outweighed by her familiarity with Columbia and with New York City's girls' schools (Barnard's pipeline for students), as well as by other qualities - namely, her sense of diplomacy and tact and her impressive educational pedigree.

The child of a New York Supreme Court judge, Putnam grew up in Canandaigua, New York, near Seneca Falls. ${ }^{30}$ After graduating with the first class of Bryn Mawr College in 1889, she continued her studies in the classics at Girton College, Cambridge, and taught briefly at Brooklyn's Packer Collegiate Institute, from 1891 to 1893, before joining the newly opened University of Chicago as a Fellow in Greek. Whereas Ella Weed was well-versed in the educational situation for women in New York City, Emily James Putnam was a scholar who had first-hand experience with a range of academic institutions and their varied approaches to women's education.

In negotiating the terms of her new position at Barnard, Putnam had secured a good salary and assurance that her job was "on the level of a professorship in Columbia." 31 Though the role of dean of women was still being defined on co-educational campuses across the country, Putnam knew that many of these women had effectively combined administration with teaching in their academic fields. This was an opportunity Putnam hoped for at Barnard, but she knew to broach the issue tactfully with President Low. ${ }^{32}$ Low agreed that Putnam should offer courses in her area of expertise, the classics. Teaching and sponsoring a Greek Club brought Putnam, as she had hoped, into daily interactions with Barnard's students, as well as with the women who were pursuing graduate studies at Columbia through registration at Barnard. Because Columbia made no formal administrative provision for the

29. Emily James Smith was later “Mrs.” Putnam, after her 1899 marriage to publisher George Haven Putnam.

30. Annette K. Baxter, “Emily James Putnam,” in Notable American Women, III: 106-8. 31. BCA, Rev. Arthur Brooks to Emily James Smith (Putnam), 21 May 1894.

32. During Barnard's early years, Columbia appointed all instructors to teach at Barnard. Further, in 1895-96 there were only three faculty men teaching at Barnard who were not connected with Columbia University. With the exception of Dean Putnam and Emily Gregory, whose anomalous status has been discussed, all Barnard instructors during the early years were men. Women could not join the Barnard faculty until the 1900 BarnardColumbia coordinate agreement. 
special needs of female students, Putnam took the initiative of working informally with Columbia's early graduate women, as did faculty wives, alumnae, and a number of the city's female philanthropists.

\section{A College Helps Build a University: Graduate Co-education and the System of Exchanges}

Putnam believed firmly that the development of Barnard College, which by now had graduated its first class and had 51 students, "would be a natural growth in relation to a direct demand." 33 Cultivating this demand would require increasing Barnard's visibility in New York City, in order to strengthen ties to donors and to the city's private "feeder" schools as well as furthering women's access to Columbia's newly formed graduate faculties. Barnard could not compete effectively with Radcliffe, Bryn Mawr, and the University of Chicago until all graduate courses at Columbia were open to women.

One of Putnam's first steps was to ask Columbia's trustees for women's admission to graduate courses in mathematics. Putnam based her arguments not on "fairness" but on data about female demand for such advanced courses (and hence possible sources of revenue) and on the excellent academic records of Barnard students enrolled in any of the various 67 graduate-level courses already open to women at Columbia. Putnam was not arguing for unrestricted co-education. For example, she acquiesced that it was inadvisable for the sexes to work together in the laboratory, given the intimate nature of certain scientific subjects and the freedom of the laboratory setting. But she was adamant that Barnard women needed training in higher mathematics to take advantage of the growing employment opportunities in New York City. ${ }^{34}$

Putnam found an ally in President Low. A progressive-minded educator, political reformer, and civic-minded philanthropist, Low believed Columbia's role in women's education was an integral part of the university's ties to the metropolis. Both administrators

33. BCA, Emily James Smith (Putnam) to Rev. Arthur Brooks, 23 May 1894.

34. Study in mathematics at Columbia was then offered in the Faculty of Pure Science, which, founded in 1893, was not specifically bound by the earlier statutes that allowed co-education within the Faculty of Philosophy. For a discussion of the need to secure advanced course work for women, see BCA, Dean Smith (Putnam) to George Plimpton, 19 Dec. 1894. 
knew that courses in political economy, history, the "new" social sciences, and mathematics would draw women to New York City, and that the city offered ample opportunities for Barnard- and Columbia-educated women to apply these skills in teaching, charity, and philanthropic work. In all, here was a "safe" alignment between women's educational needs and Columbia's need for tuition-paying students to fund expansion and development. For these reasons, and because he wanted to challenge John Burgess, dean of the Faculty of Political Science who opposed co-education, Low added to Putnam's original request his own inquiry about opening Columbia courses in history and political economy to women. It would be "idle" for Columbia to "attempt to stem the tide of women's higher education or to be antagonistic toward a movement which commends itself to intelligent people...the world over." Echoing Putnam's plea for Columbia to be an "agent of the community," Low warned Columbia's trustees that if Columbia refused to meet the educational needs of the women of New York, one of its "principal competitors" would. ${ }^{35}$

But competition alone could not move the trustees to broaden co-education. They remained ambivalent about co-education and denied Putnam and Low's proposals. Soon thereafter, an anonymous gift to Barnard College (in fact from Low himself) enabled Putnam to offer Barnard students instruction in economics and history. Barnard's first faculty hires through Columbia were three promising scholars, the economist John B. Clark, from Amherst; the historian James Harvey Robinson, from Pennsylvania; and the mathematician Frank N. Cole, from Michigan. ${ }^{36}$

Putnam's judgment in appointing men of this calibre and promise, who might easily have joined a university faculty, changed Barnard College's fortunes dramatically. The women's college now stood at a pivotal juncture in fashioning its own character and possibly shaping a new relationship to its host university. Should Barnard "begin the appointment of professors of its own, approved by Columbia, but practically independent of

35. See BCA, President Low's letter to the University Council, 16 Oct. 1894. Indeed, Columbia risked lagging behind its reference group. Low noted that Harvard had 59 courses open to women, that Yale had adopted graduate co-education, that Scottish universities accepted women, and that even some German universities now offered limited education to women.

36. These men were offered generous salaries. For exact figures, see BCA, Low to Miss Smith (Putnam), 8 Apr. 1895. Also see White, Barnard College, 30-1. 
it?” Putnam asked, hesitantly. ${ }^{37}$ Indeed, Barnard might have fulfilled its goal of providing women with instruction equivalent to men's by maintaining a separate Barnard graduate faculty-following, for example, the Bryn Mawr model or Vassar's brief experiment, from 1886 to 1894, in conferring the Ph.D. But Emily James Putnam, like her predecessor Ella Weed, believed in the principle that "Barnard is Columbia."38 As Helen Horowitz aptly observes, Putnam "sought to lead women into the university, not to replicate its offerings at Barnard."39 To Putnam's mind, the preferable course of action and surer path to Barnard's continued excellence was to forge stronger, mutually beneficial ties with Columbia - thereby adding to the "prestige and effectiveness" of the university from which Barnard "draws its own strength.",40 Capitalizing upon the leverage afforded by Columbia's building aspirations and staffing constraints, Putnam offered the teaching of her social science faculty in an even hour-for-hour exchange for the teaching services of Columbia professors. ${ }^{41}$ The system of exchanges that developed enabled Barnard students to study with university professors and over the years strengthened collaboration between Columbia's departments in arts and sciences and the various parallel disciplinary units at Barnard. ${ }^{42}$ Such ties added substance to the rhetoric that "Barnard is Columbia" that set Barnard apart from its closest rival Radcliffe and made Barnard, as one faculty member put it, "far more distinctively a place for graduate work than...any other women's college." ${ }^{43}$ By 1898, all graduate faculties at Columbia admitted women for degree study.

37. CUCF, Extract from the Minutes of University Council, Emily James Putnam to Seth Low, 15 Jan. 1895.

38. Meyer, Barnard Beginnings, 46. Also see BCA, Ella Weed to Silas Brownell, 28 Oct. 1890.

39. Horowitz, Alma Mater, 137.

40. BCA, Dean's Annual Report, 1895.

41. Mabel Louise Robinson, Curriculum of the Women's Colleges (Washington, D.C.: Government Printing Office, 1918), 15; for a discussion of the salaries, see BCA, Seth Low to Emily James Smith (Putnam), 8 Apr. 1895.

42. This system undergirded co-ordination until an exchange of fees was introduced in 1922.

43. Brewster, "Barnard College, 1889-1909," 179. 


\section{Institutionalizing a Vision of Women's Liberal Arts Education, and Building a Campus}

The early achievements of Putnam's deanship-namely, developing a system of Barnard-Columbia exchanges that helped diversify curricular offerings, and helping to gain admission for women to all graduate faculties in the arts and sciences at Columbia-bolstered Barnard's standing as a liberal arts college for women. These steps were crucial in advancing Barnard's ability to compete with the established eastern women's colleges, especially its closest rival, Harvard's Radcliffe. But as Barnard's four-year probationary period ended, Dean Putnam and the Barnard trustees still faced the substantial difficulties of sustaining financial support for the college. Furthermore, the continued viability of coordinate education, which depended heavily on Barnard's physical proximity to Columbia, seemed less certain as the university made plans to move to the area in upper Manhattan known as Morningside Heights. Under Putnam's skilled leadership, enabled by the receipt of a series of gifts from "self-sacrificing" ladies, Barnard was able to give shape and form to its ideas about women's education by building an uptown campus, complete with a dormitory facility, alongside Columbia's new campus. ${ }^{44}$

Though building a campus was a crucial step in building a liberal arts college, Putnam looked to the future. Barnard was outgrowing the original co-ordinate framework. In particular, female students still needed broader and more equitable opportunities for graduate and professional study as well as the chance to observe and study with accomplished scholarly women. By this point, the title of Barnard's first woman instructor, Emily Gregory, had been changed to "Professor of Botany at Barnard College," but the event, for reasons related to Barnard's co-ordinate ties to Columbia, did not produce a watershed or opening wedge for academic women at Barnard or Columbia. Gregory found herself in an unusual circumstance: she taught at a college for women that was administered by a woman and by a board of trustees with significant female representation, but she felt isolated

44. BCA, Abram Hewitt to Silas Brownell, 4 Oct. 1898. In 1896 May Van Wyck Brinckerhoff pledged $\$ 100$, 000 on the stipulation that within four years Barnard would move within 1,000 feet of Columbia. Trustee Elizabeth Anderson donated \$170,000 to build a main building in 1896 and in 1897 Mrs. Josiah Fiske donated the first dormitory. Also see Horowitz, Alma Mater, 134-42. 
and excluded-a "lone voyager." 45 Her change of title notwithstanding, Gregory realized that Columbia would offer her "none of the usual advantages" accorded a person of her rank and that she would have "no opportunity of conferring with other Professors in regard to course of study, plans for original work...I would be cut off from all the help which comes from association with the teaching and governing body of an institution." 46

For Putnam, securing opportunities for scholarly women to teach and conduct research at Barnard had a high priority as she and Low negotiated the terms of Barnard's formal affiliation with Columbia University. Though Low was generally sympathetic to the cause of women's education, he felt that certain limits to the Barnard experiment were prudent. It would be "worse than idle to propose to amalgamate the two faculties...it is illogical and undesirable," he confided to Putnam. "Barnard could either be a separate college that received the same degree or could follow a course laid down for men, without regard to women, which shall be pursued from choice by the women." 47

Putnam, who had grown impatient with the principle of advancing women through Barnard's subordination to Columbia, hoped to negotiate a co-ordinate agreement that would enable Barnard to shape its own identity. "Up to this time Barnard has been without a voice in its own academic policy. Where the needs of our students have been different...we have had no official means of meeting them...Barnard has been subordinate, not only to the president of the university, but to Columbia College," 48 Putnam wrote. As dean, Putnam was not permitted to decide any case at Barnard on its merits, but had to follow Columbia. Even Barnard's instructional schedule was constrained by the existing relationship because time slots were assigned first to Columbia.

In the end, Putnam's sustained advocacy paid off. An agreement of university co-ordination signed between Barnard and Columbia in 1900 was a crucial step in achieving a voice for women in university-wide policy-making and in institutionalizing

45. The type of isolation that Gregory described has been most fully documented in relation to the experience of women at co-educational institutions. See Clifford, Lone Voyagers, 1-46.

46. White, Barnard College, 29-30; BCA, Emily Gregory to Dean Emily James Smith (Putnam), 24 Jan. 1895. Unfortunately, Gregory died in 1897, three years before Barnard achieved formal university affiliation and the opportunity to appoint women to the Barnard faculty.

47. BCA, President Low to Dean Putnam, 28 Nov. 1899.

48. Emphasis added. BCA, Emily James Putnam to Abram S. Hewitt, 18 Jan. 1900. 
a vision for women's undergraduate and graduate education at Columbia University. The agreement placed Barnard in sharp distinction to the "unsatisfactory footing on which Radcliffe and the English colleges for women stand." ${ }^{49}$ Barnard now had the possibility of making its own decisions rather than slavishly following Columbia. Though Putnam was unsuccessful in securing women's unconditional admission to graduate studies, women would now have their Master's and Ph.D. degrees awarded from the university, on the same terms as men. ${ }^{50}$ Having first employed Columbia men and then, thanks to Putnam, diversified its curricular offerings through a system of faculty exchanges with Columbia, Barnard now could recruit and maintain its own faculty, to be appointed directly by the Columbia trustees. Faculty would be of university standard but their energies and allegiance, at least in theory, would be directed to the health and advancement of Barnard. And, as the sympathetic Seth Low assured Putnam, the intra-university agreement clarified that "members of the Faculty of Barnard College may be either men or women." 51 Further, Barnard College, and hence the concerns of women's education, would have voting representation on Columbia's newly formed University Council by its dean and two elected Barnard faculty members. $^{52}$

Despite the three major achievements of her deanship-first, convincing Barnard's reluctant trustees that she could satisfactorily fulfil the role of dean after her 1899 marriage to publisher George Haven Putnam (when the few other female heads of the eastern women's colleges were single); second, developing a system of faculty exchanges between Barnard and Columbia; and third, negotiating the landmark co-ordinate agreement of 1900-Putnam knew that there were limits to what could be accomplished and that Barnard College officials, including her closest ally Annie Nathan Meyer, would not sanction a woman combining the deanship and

\footnotetext{
49. Ibid.

50. Until this point, women who attended Columbia's graduate courses registered through Barnard. A total of seventy-four women earned their advanced degrees at Columbia under this early arrangement: 68 master's degrees and 6 Ph.D.s. See BCA, Virginia Gildersleeve to Thomas Woody, 7 Apr. 1927. The arrangement for women's graduate education at Columbia University was more liberal than at Harvard University, where Radcliffe began awarding the Ph.D. only in 1902 and women could not earn a Harvard Ph.D. until 1963.

51. Emphasis added. BCA, Seth Low to Silas Brownell, 18 Mar. 1901.

52. Virginia Gildersleeve, Many a Good Crusade: The Memoirs of Virginia Crocheron Gildersleeve (New York: Macmillan, 1954), 66.
} 
childrearing. Some individuals, like Barnard supporter Everett Wheeler, did argue that Putnam should be allowed to return to the deanship, citing the example of England's Mary Somerville. ${ }^{53}$ But so powerful were beliefs about celibacy for academic women or at least devotion to only one job (family or career) that Putnam resigned in 1900, feigning a serious illness rather than publicly announcing her pregnancy. ${ }^{54}$

\section{Laura Drake Gill: An Imperfect Fit and the Undoing of a Dean}

Putnam left Barnard on a solid academic footing, but the young college was in search of leadership for the second time in less than a decade. Again, the trustees, this time more concerned about the issues raised by Putnam's departure, debated whether Barnard's dean should be a man or a woman. In the end, they remained convinced that the only liberal arts college open to women in New York City needed to be headed by a woman. By January 1901, Barnard's trustees together with President Low had settled on Laura Drake Gill, a native of Chesterville, Maine, and a Smith College alumna, Class of 1881. Having studied higher mathematics in Leipzig, Paris, and Zurich, she was familiar with university life. Gill came to Barnard with seventeen years of high school teaching experience and several years of philanthropic service with the Red Cross in Cuba after the Spanish-American War. ${ }^{55}$

The few records that exist concerning Gill's appointment suggest that some educators were not fully convinced that she was suitable for the Barnard post, given the complexity of Barnard's coordinate relationship to Columbia and the demands of Manhattan society. ${ }^{56}$ Low knew that the appointment was "experimental from certain points of view," and justified his support for Gill by referring to an observation made by his friend Benjamin Wheeler that whereas alumnae of the University of California chose to

53. BCA, Everitt Wheeler to George Plimpton, 19 Mar. 1900.

54. BCA, Emily James Putnam to Silas Brownell, 13 Jan. 1900.

55. Obituary, New York Times, 5 Feb. 1926.

56. Wellesley's president Alice Freeman Palmer did not regard Gill as a "woman built on a large plane," while Harvard's president Charles Eliot felt that she would not be "winning to cultivated girls." These observations are related in M. Carey Thomas to Seth Low, 27 Nov. 1900; and Charles Eliot to Seth Low, 8 Dec. 1900, both in Box 8, Dwight Miner Papers, Columbia University Rare Book and Manuscript Room, Columbia University (hereafter cited as Miner Papers). 
attend Harvard to study the humanities, "for every study that touches life, they come to Columbia." Low in turn asserted that "it is because Miss Gill's experience has touched life so broadly that I am especially hopeful she will fit harmoniously into the Columbia atmosphere." 57

Beyond these basic biographical facts, little is known about Laura Drake Gill other than that her Barnard years were turbulent. She managed to alienate far too many potential and important would-be allies in her short tenure. For example, as Bette Wenecke has shown, Gill's criticism of the calibre of students who crossregistered at Barnard from Teachers' College reflected institutional and class biases that provoked the ire of Teachers' College president James Earl Russell. ${ }^{58}$ Gill's leadership concerns and style estranged a substantial number of Barnard College alumnae, many of whom lived in the Greater Manhattan area and were keenly interested in their alma mater's affairs. But perhaps most costly was Dean Gill's frequent conflict with Columbia's formidable president and Seth Low's successor, Nicholas Murray Butler.

Through effective fund-raising Gill contributed in lasting ways to developing Barnard's bricks and mortar, but she continually struggled to hit her stride as dean. One particularly difficult issue that Gill inherited from Putnam's administration-left unresolved and clouded by the reasons for Putnam's resignation-was the question of marriage and family life for Barnard's female faculty. Gill's decision in the case of Professor Harriet Brooks, a talented Barnard faculty member and promising physicist who asked to retain her position after marriage, shows that the demands and pulls of academic culture, especially the complexities of the co-ordinate setting, might divide women. Gill's adherence to the status quo, even when the faculty encouraged her to be a force of change, underscores that contending factors and concerns shaped decanal decisions. In July of 1906, Gill received a letter from Brooks about her engagement and plans to marry Professor Bergen Davis of the Columbia Physics department. ${ }^{59}$ Believing that Brooks's case was

57. BCA, Seth Low to Silas Brownell, n.d. [Jan. 1901].

58. Bette Wenecke, "Social and Cultural Stratification in Women's Higher Education: Barnard College and Teachers College, 1898-1912,” History of Education Quarterly 31 (Spring 1991): 1-25.

59. Brooks had trained in Canada with Rutherford, been a mathematics tutor at McGill University, and was among the earliest recipients of a prestigious European fellowship from Bryn Mawr. For details of this episode, see Marelen Rayner-Canham, Harriet Brooks: A Pioneer Scientist (Montreal: McGill-Queen's University Press, 1992). For an obituary, see “Harriet Brooks (Mrs. Frank Pitcher),” Nature 131 (June 17, 1933): 865. 
straightforward, Gill wrote to Silas Brownell, Chairman of the Board of Trustees, asking for confirmation that Brooks would be expected to resign. "The wishes of the Trustees were freely expressed to me five years ago...I infer that their wishes would extend to any woman on the staff." 60

On learning that Dean Gill was not receptive to her request to remain on the Barnard faculty after her marriage, Brooks protested on principle, asserting that her individual case embodied a question of women's group rights. "It is a duty I owe to my profession and to my sex to show that a woman has a right to the practice of her profession...I cannot conceive how women's colleges, inviting and encouraging women to enter professions can be justly founded or maintained denying such a principle,” Brooks wrote. ${ }^{61}$

Gill found herself in an awkward position. She had the opportunity to question the trustees' views and to seek an allowance for Brooks, but she was wary of being drawn into any avoidable conflict and was herself unconvinced that a woman could satisfactorily combine marriage and professorial duties. Her decision to uphold the policy of allowing only single women on her faculty, not unlike Weed's position vis-à-vis suffrage, reflected a socially conservative strategy for Barnard's advancement. "I feel very strongly that a woman may carry on many lines of scientific work after marriage, but not class room work whose interruption should be detrimental," Gill wrote to trustee Silas Brownell. "I may be wrong, but I interpret the question of finance to be even more potent than that of sex solidarity."62

Gill's response reflected how varied were the views regarding the balance between marriage and career adopted by women situated differently within the same educational institution. While Brooks hoped Barnard would be forward-looking and latitudinarian, Gill interpreted Barnard's interests conservatively and defended the status quo. Like her predecessors in their attempts to disentangle women's education from the volatile suffrage issue, Gill expressed her concern for Barnard's public image: "The College cannot afford to have women on the staff to whom the college work is secondary; the college is not willing to

60. BCA, Laura Gill to Silas Brownell, 28 July 1906.

61. Harriet Brooks to Dean Gill, 18 July 1906, quoted in Rayner-Canham, Harriet Brooks, 46-8.

62. Emphasis added. BCA, Laura Gill to Silas Brownell, 28 July 1906. 
stamp with approval a woman to whom self-elected home duties can be secondary." 63

In part, that concern with Barnard's public image led to Gill's own resignation in late 1907 . Her decision to leave was precipitated by her repeated friction with Columbia's President Butler and by substantial public pressure generated by a Barnard College alumnae petition calling for her to step down. ${ }^{64}$ At issue were perceived shortcomings in Gill's personal sensibilities and leadership skills. Gill was criticized for lacking tact and prudence and, notably, for overseeing Barnard as an old-fashioned women's seminary rather than an elite, urban woman's college. ${ }^{65}$ This last criticism underscored the class and cultural assumptions that shaped Barnard's self-image, as did Silas Brownell's suggestion that Gill rephrase her letter of resignation, editing any reference to “radical differences” with Columbia’s administration. "May I say that I think it would be a distinct hindrance to the progress of Women's management of Educational Institutions to have such a contest projected into the management of Barnard College as your communication to the Executive Committee may precipitate," he wrote. "This suggestion arises," he later underscored his point, "from the interest I have that college women, and especially managers, transact their offices becomingly."66

\section{Should the Dean of Barnard Be A Man? If Not, What Type of Woman?}

In the wake of Gill's stormy tenure and bitter departure, the deliberations of Barnard's trustees again centered on the qualities Barnard needed in a leader. Should Barnard's new dean be a man or a woman? What qualities did a new dean need to represent

63. Dean Gill to Harriet Brooks, 30 July 1906, quoted in Rayner-Canham, Harriet Brooks, 48.

64. Gill went on to a notable career in the Vocational Bureau for College Women, as president of the Association of Collegiate Alumnae (1908-1912), and as a settlement worker at Berea and Sewanee. For details of Gill's career in education and her service activities, see her obituary in the New York Times, 5 Feb. 1926.

65. Gill resigned following a seven-month leave of absence, still deeply embittered by her interactions with students, alumnae, and both college and university administrators. See BCA, Gill to Brownell, 3 Dec. 1907; and "Barnard Dean Resigns," New York Tribune, 29 Dec. 1907.

66. BCA, Silas Brownell to Laura Gill, 26 Nov. and 2 Dec. 1907; and Laura Gill to Silas Brownell, 27 Mar. 1907. 
Barnard at Columbia, as well as to solidify Barnard's influence in issues related to girls' schooling and higher education for women in New York City? Advice and nominations were solicited from prominent educators nationwide.

With the exception of interim appointments, when faculty men stepped in, Barnard had always been headed by a woman. By now, though, Barnard was sufficiently important and the dual demands of administering an undergraduate college and navigating collegeuniversity relations were sufficiently complex that, according to many interested parties, gender considerations should figure prominently in Barnard's appointment of a dean. Gender had, in fact, always mattered in the Barnard trustees' expectations of their dean, but the balance of opinion had changed, and for the first time in Barnard's short history there was considerable support for naming a male dean. This option was advocated by a number of Barnard's faculty, particularly senior men. Franklin Giddings, who had formerly taught at the formidable M. Carey Thomas's Bryn Mawr, thought a dean of the same sex was "both mentally and morally" damaging to impressionable students. ${ }^{67}$

Perspectives were mixed among women. Barnard trustee Clara Spence, headmistress of an elite Manhattan girls' school, argued for a "well-dressed woman," and even volunteered to subsidize the salary once a suitable candidate was found. ${ }^{68}$ A few people espousing traditional views of gender sought a compromise by suggesting that an administrative duo would capitalize on the strong and ostensibly complementary qualities of both sexes. As one female respondent put it, Barnard might be headed by an "executive man" and a "magnetic woman."

The Gill fiasco and the protracted search for a new dean brought a re-examination of Barnard's relationship to Columbia University and close scrutiny of the dean's office at Barnard. Barnard's Silas Brownell, speaking on behalf of the trustees, put consideration of undergraduate students first, by asserting that "Barnard needs a head, whose allegiance shall be due and paid to her rather than to the University...an Executive Head, independent of all outside control, responsible only to Barnard's Trustees."70 By contrast, Columbia's President Nicholas Murray Butler asserted that the

67. Miner Papers, Box 8, Franklin Giddings to Nicholas Murray Butler, 27 Jan. 1908. 68. Spence would eventually be offered the position but would decline the deanship. BCA, Clara Spence to George Plimpton, 7 May 1908.

69. Miner Papers, Box 8 "Notes on Deanship," 12.

70. CUCF, Silas Brownell to Nicholas Murray Butler, 7 Jan. 1908 and 31 Dec. 1907. 
university did not constrain the college, and, in fact, that the university's pull would bring Barnard top-calibre leadership: "Barnard College, because of its membership in Columbia University, can command the services as Dean of persons...who would not for a moment consider accepting the Presidency of Barnard College as a separate institution, or the Presidency of Bryn Mawr, Vassar or Smith."71 A third and ultimately persuasive point of view was expressed by a number of others, perhaps most notably George Kirchway, Dean of Columbia’s Law School. He noted the "double nature" of Barnard's affairs, which encompassed academic and social functions, and suggested that the duties of the office be divided. "This solution of the problem has been adopted in one or more colleges for women, notably at Radcliff [sic]. I imagine that the Dean of Women at Chicago and other Universities...perform only the secondary function....and have no responsibility for educational administration...The person to shape the intellectual ideals of the institution should be a man-or at least, a masculine woman, with a feminine woman to fill the other role," Kirchway advised. $^{72}$

The tensions brought to a head by Gill's missteps were exacerbated by a number of other factors - among them, Barnard's loss of a number of male faculty members to the university, a push toward specialization and consolidation in higher education, and the temper of an era that saw a "backlash" against women's advances at campuses where they had excelled (for example, Chicago, Wisconsin, and Wesleyan). ${ }^{73}$ In the end, Columbia successfully engineered a less powerful or at least more socially oriented female deanship for Gill's successor (a position more akin to the position of Dean of Women at most co-educational universities) while also creating the new position of provost (for a faculty man) to assume fiscal responsibility and oversight of university relations. $^{74}$ The intended distribution of power and authority between the newly configured Barnard deanship and the

71. CUCF, Nicholas Murray Butler to Silas Brownell, 2 Jan. 1908.

72. CUCF, George Kirchway to Nicholas Murray Butler, 8 Jan. 1908; and William Brewster to Nicholas Murray Butler, 21 Sept. 1909.

73. For a discussion of the trend toward specialization, see Laurence R. Veysey, The Emergence_of the University (Chicago: University of Chicago Press, 1965), 263-341. The "backlash" against women is discussed in Rosenberg, Beyond Separate Spheres, Part I.

74. William Brewster, who joined the Barnard faculty in 1894, served as Acting Dean from June 1907 to February 1911. Chosen as Provost of Barnard College in 1911, Brewster served in that capacity until returning to his full-time faculty role in 1923. 
new post of provost reflected traditional gender roles and expectations: "The first class of duties devolve upon a woman, whereas the second group can for rather obvious reasons be entrusted to a man. A great part of what is best worth doing in this world is accomplished informally, and a man has a great advantage in being able to transact business and consult with his fellow men at luncheon, or as he runs across them on the campus. Prearranged conferences in the dean's office need rarely occur." ${ }^{\text {, }}$ In congratulating the newly appointed provost, Professor William Brewster (who was then Barnard's acting dean and longest serving faculty member), the editors of the Columbia University Quarterly concluded that "it should not be difficult to find a woman to fill the somewhat simplified but still most essential and exacting office of dean." 76

\section{Virginia Crocheron Gildersleeve: An Alumna and a New Yorker Leads}

The woman who possessed the decanal skills needed to repair the damaged fabric of co-ordinate education and to continue the building of Barnard's identity as a leader within Columbia University and women's education nationally was Virginia Crocheron Gildersleeve. A "born and bred" New Yorker, she attended Brearley, one of Manhattan's elite private girls' schools, and Barnard (Class of 1899), where Dean Putnam and Nicholas Murray Butler were her professors. Undertaking her graduate studies at Columbia, Gildersleeve earned her master's degree in political science and after completing her Ph.D. in English literature in 1908 became a regular member of Barnard's faculty.

Gildersleeve's promise as a strong leader was evident even before she assumed office. Dissatisfied with the weakened authority of the newly configured deanship, Gildersleeve, with Butler's counsel and aid, persuaded Barnard's trustees to restore decanal powers vis-à-vis budgets and academic appointments. ${ }^{77} \mathrm{~A}$ Columbia "insider," the politically savvy Gildersleeve had a deep

\footnotetext{
75. Editorial Comment, "Provost and Dean of Barnard College,” Columbia University Quarterly 12 (Mar.1910): 308-9. For discussion of the position of provost, see CUCF, Nicholas Murray Butler to William T. Brewster, 17 Oct. 1908; and White, Barnard College, 63.

76. Editorial Comment, "Provost and Dean of Barnard College,” 309.

77. Gildersleeve, Many a Good Crusade, 62-6.
} 
philosophical grasp of Barnard's liberal arts mission and of the college's relationship to the university. But perhaps most important, she enjoyed a type of enabling rapport with Butler that New Englander Laura Gill never did. ${ }^{78}$ In Gildersleeve's estimate, Gill had misguidedly assumed a maternal rather than a cerebral role at Barnard and had unwisely played the Barnard trustees off President Butler. ${ }^{79}$ Gildersleeve, by contrast, cultivated intellectual culture on campus and used her considerable personal connections among alumnae, trustees, colleagues, and family to advance Barnard's interests in the university and the city, and beyond.

When Gildersleeve became Barnard's dean in 1911 there was still no office at Columbia corresponding exactly to the Dean of Women, even though the position existed at many co-educational institutions, and Columbia (which in 1910-1911 had 546 female students) had already completed a decade of graduate coeducation. ${ }^{80}$ Though Gildersleeve's official duties differed "very radically from those of the usual Dean of Women,"81 and, in fact, were increasingly more comparable to the presidency of a women's college, she believed Barnard must then serve as Columbia University's conscience in matters related to women's education. She became an eloquent and well-respected advocate on behalf of women - students and faculty-across the university.

One of Gildersleeve's earliest actions was to make plans for the university women's lounge to be moved from a remote dormitory space to a new home in Columbia's soon to be opened Philosophy Hall, located centrally on campus. Further, she replaced her somewhat amorphous duties as "Adviser to University Women" with an active university committee on Women Graduate Students, whose members included the "new" historian James Harvey Robinson, the Progressive philosopher John Dewey, and the economist and scholar of women's affairs Emile Hutchinson. ${ }^{82}$ The committee addressed many of the issues that the Graduate

78. Tapped to become her alma mater's dean, Gildersleeve was eager to serve. With the counsel and aid of her former professor of philosophy, soon to be colleague, Columbia President Nicholas Murray Butler, she gained the sympathetic ear of Barnard's trustees and succeeded in re-establishing the integrity of the dean's position and its power vis-à-vis budget and policy-making. The rapport and respect between Gildersleeve and Butler was not an insignificant factor in Gildersleeve's long, successful tenure at Barnard, and her ability to forge broader opportunities for women students and faculty.

79. For this characterization, see Gildersleeve, Many a Good Crusade, 52-8.

80. Miner Papers, Box 28, Report of Committee (1911).

81. BCA, Gildersleeve to Irma Voight, 3 Oct. 1913.

82. BCA, Gildersleeve to Frank Fackenthal, 27 Jan. 1916. 
Women's Club at Columbia had raised since the university's first group of female graduate students organized for support and camaraderie in 1895. Among their concerns were improving the quality of academic advising and career guidance for women, and working to equalize women's access to fellowships, meeting space for activities, and university courses. One tangible outcome of this committee's work was the building of Johnson Hall, a graduate dormitory for women. This much-needed facility brought Barnard and Columbia a competitive advantage in attracting female students to New York City. ${ }^{3}$ Her commitment to bringing the needs of female students to the attention of the university's administrators made Gildersleeve seem, as one particularly appreciative female graduate student put it, like a "dea ex machina."

By the end of her first decade as dean, Gildersleeve had developed a rapprochment between Barnard and its local alumnae (a relationship that had suffered during Gill's tenure). She had marked Barnard's twenty-fifth anniversary with a successful twomillion-dollar fund-raising campaign for endowment and had secured the gift of a student building, Schiff Hall. This facility included a gymnasium (central to promoting women's health and preparation for certain careers), lounges, and reading rooms-all needed to build a campus community at the urban, predominantly commuting college. Jacob Schiff, the donor, who had served briefly as Barnard's first treasurer, envisioned his gift as an ecumenical home for the "social and ethical activities of the entire female student body," bringing to women from all divisions of the university "in a small and economical way the advantages which the men now enjoy." $" 85$

The list of Gildersleeve's contributions is lengthy. Representative among them were her efforts to build campus life by strengthening student government and activities in an era when students themselves denounced the exclusivity and frivolity of "fraternities." 86 Her own admiration for classical and literary

83. In order to meet the daily needs of female students Gildersleeve instituted a series of reforms that transferred responsibilities previously overseen in the Barnard Dean's Office to a number of dormitory officials at both Barnard College and Columbia University. 84. Columbia University, Columbiana Collection, Anna Campbell, "A History of the Women's Graduate Club of Columbia University, 1895-1925,” typescript dated Apr. 1927, p. 6.

85. BCA, Jacob Schiff to George Plimpton, 24 Aug. 1915; and James Earl Russell to Felix Warburg, 15 July 1915.

86. "Barnard College Puts the Ban on Secret Societies,” New York Times, 8 June 1913; and Freda Kirchway, “Fraternities Versus Democracy,” Barnard Bear 8 (Oct. 1912): 2-6. 
training aside, she updated Barnard's curriculum by abolishing compulsory Latin, introducing physical education, and establishing a system of student advising. She defined Barnard's success not only in terms of Columbia, as Ella Weed had done by necessity, but in terms of providing a useful education for modern women. In part, this meant working with New York City's private headmistresses to encourage college preparation for the city's female students, and in part, this meant connecting Barnard to educational debates and networks beyond New York City.

Gildersleeve adamantly opposed vocationalism in higher education, yet she believed Barnard needed to create new paths for educated women, to provide a broader range of alternatives for women to consider in addition to the traditional option of teaching. Toward this goal, Gildersleeve negotiated arrangements so that Barnard seniors might dovetail their final year with training at Columbia's professional schools or affiliates - in the fields of journalism, philanthropy, and business. She even tackled the barriers at Columbia that excluded women from preparation for the prestigious and traditionally male-dominated professions of medicine and law. Determined to enable women to gain access to this training - the gateway for women's entry to the new fields of public health, for instance-Gildersleeve buttonholed administrators of Columbia's professional schools to support women's admission. Courting both philanthropic support and public opinion, she worked behind the scenes to provide the needed "opening wedge" for women and then assured the initiative's success by promoting the highest calibre women as "test" candidates. Gildersleeve's efforts were not inconsequential in opening the door for women to Columbia's medical school in 1917, and the law school in $1926 .{ }^{87}$

\section{The Divided Deanship is Whole Again}

Under Gildersleeve, Barnard gained greater prominence in Columbia University affairs. Not insignificantly, when William Brewster retired in 1923 the position of provost, which, one recalls, had been founded after Gill's departure, was abolished.

87. Gildersleeve helped to establish evening law classes in the Extension Division. She also consulted with her father, a Supreme Court Justice, concerning the possibilities of using the evening classes as an "opening wedge” for securing women's legal training at Columbia. 
Gildersleeve had effectively consolidated the deanship. The longstanding goal of integrating Barnard more fully into university affairs - a measure consonant with Barnard's internal efforts to provide women with an education equivalent to men's-was accomplished by appointing Gildersleeve in her capacity as Barnard's dean to the university's Advisory Committee on Educational Policy. ${ }^{88}$ Of far greater importance, Gildersleeve was instrumental in guiding Barnard to the level of maturity and confidence needed to diverge from Columbia, not along sex lines, but along conceptions of education and pedagogy. While in the post-World War I years Columbia introduced the Contemporary Civilization survey, and later developed its distinctive approach to general education, Gildersleeve focused on sponsorship of visiting professors, the development of courses introducing students to the distinct approach and questions of each discipline, and an elite honours curriculum for the college's most talented students. Interdisciplinary work would follow and become a hallmark of Barnard's curricular innovativeness. ${ }^{89}$

Like most of her contemporaries at northeastern colleges, Gildersleeve's record on issues of race, religion, and ethnicity was not unblemished. ${ }^{90}$ That said, Barnard's urban setting and the predominance of commuting students at Barnard created a campus that overcame some of the intellectual and social isolation associated with the bucolic women's colleges. Moreover, Gildersleeve held high academic goals for all students and did much to help develop a rigorous and distinctive curriculum for Barnard undergraduate education. She also instituted a number of forward-thinking policies that enriched professorial life at the college. Though Barnard's women scholars encountered certain gender-related biases and barriers that their male counterparts did not, the types of initial advances that Emily James Putnam had envisioned for faculty women, as she negotiated the 1900 BarnardColumbia agreement, became evident during Gildersleeve’s tenure.

88. BCA, Dean's Annual Report, 1923.

89. Virginia C. Gildersleeve, “A Curriculum for Today,” Proceedings of the National Association of Deans of Women (1935), 111.

90. For views concerning anti-Semitism at Barnard, see Lynn D. Gordon, “Annie Nathan Meyer and Barnard College,” History of Education Quarterly 26 (Winter 1986): 515, 521; and Rosalind Rosenberg, "The Legacy of Dean Gildersleeve,” Barnard Magazine 84 (Summer 1995): 17-21. For Barnard's position concerning African-Americans, see Linda Perkins, "The African American Female Elite: The Early History of African American Women in the Seven Sister Colleges, 1880-1960," History of Education Quarterly 67 (Winter 1997): 742-3. 
By 1915-16, about one-third of the 97 Barnard College faculty gave instruction only at Barnard, and all but six of these were women. ${ }^{91}$ Beginning in 1920, women comprised the majority of the Barnard faculty. ${ }^{92}$ Though Gildersleeve remained single, sharing her life with the literary scholar Caroline Spurgeon and, in the years after Spurgeon's death, Elizabeth Reynard, the concerns of faculty women who did marry were evident in her decanal decisions. Whereas in an earlier era Barnard's female faculty had been obliged to remain single, Gildersleeve allowed Barnard's academic women to be married and was in the vanguard of college administrators in introducing the policy of paid maternity leave. ${ }^{93}$

These forward-looking faculty policies notwithstanding, Gildersleeve, like her predecessors, followed a judicious path that sought to advance women's cause while preserving Barnard's standing in the university and drawing strength and prestige from that association. While Gildersleeve's critics thought that Barnard as a leading women's college was obligated to hire more women, primarily to offset the effects of substantial gender discrimination elsewhere, Gildersleeve was more ambivalent about such strategies. She once described arriving at what might be the optimal level of female representation on Barnard's faculty as a "puzzling problem." "A4 As she explained in her autobiography, "We could, as a rule, secure for an assistantship a better quality of woman than a man. Thus if we filled our higher posts only by promotions from below, we tended to acquire a faculty predominantly feminine. Was this a good thing? I was inclined to think it was not...It was our first obligation to provide the best professors we could secure for our students irrespective of sex."95

If Gildersleeve was more comfortable capitalizing on the added diversity and prestige of a mixed faculty at Barnard than were her critics, she was willing to pursue broader opportunities and higher status for Barnard's faculty women at Columbia University. In 1922, a revision of the university statutes gave Columbia approval over Barnard's permanent appointments and allowed Barnard faculty with the rank of associate professor, including women, to teach in Columbia's arts and sciences. ${ }^{96}$ This action eased the path

91. Robinson, Curriculum of the Women's Colleges, 44.

92. Robert A. McCaughey, "A Statistical Profile of the Barnard College Faculty, 1900-

1974” (mimeograph, Department of History, Barnard College, 1975), 16.

93. Former dean Putnam returned to the history faculty in 1914.

94. Gildersleeve, Many a Good Crusade, 78.

95. Ibid. Emphasis in the original.

96. CUCF, Butler to Gildersleeve, 3 Dec. 1930. 
for women, if ever so slightly, to get assistantships, lectureships, and lower-rank appointments in Columbia's graduate faculties. ${ }^{97}$ Another example of Gildersleeve's insistence that there were benefits to collaboration among men and women and that "divisions [in an academic community] should not be made by sex lines" ${ }^{\text {" }}$ were her diplomatic efforts to challenge women's exclusion from campus settings where a great deal of informal decisionmaking occurred, such as the Men's Faculty Club. Gildersleeve worked closely with Teachers' College's historian of education Willystine Goodsell and sociologist of education Mabel Carney to find ways for faculty men and women to benefit from informal contacts. Having encountered substantial resistance to the idea of a co-educational faculty club, Gildersleeve and her colleagues challenged university plans that would accommodate the Men's Faculty Club in a new building but provide no space for the Women's Club (founded in 1913). Ironically, Gildersleeve's efforts to broaden collegiality among the sexes met the toughest resistance from men on the Barnard faculty who saw the Men's Faculty Club as their last "refuge from a female world.",99

\section{Opening Barnard to the World: The Dean as Promoter of the Women's College}

Gildersleeve's distinctive role as an educational stateswoman beyond Columbia University was achieved by her leadership in national policy-oriented organizations, such as the College Examination Board and the American Council on Education, in helping to found the International Federation of University Women in 1919, and in galvanizing the Seven Sisters movement in the 1920s. Over the years, holders of the Barnard deanship had looked to men at Columbia, to presidents of the women's colleges, and to other deans of women for models of leadership and for inspiration in addressing the needs of their co-ordinate setting. Under Gildersleeve, the orientation and stature of Barnard's dean, while continuing to derive strength from association with Columbia, became more closely aligned with the concerns of female colleges

97. White, Barnard College, 100.

98. CUCF, Virginia Gildersleeve to Nicholas Murray Butler, 14 Nov. 1921.

99. CUCF, Mabel Carney, quoted in Ida A. Jewitt, Women's Faculty Club of Columbia University,1913-1963, typescript. Also see CUCF, Virginia Gildersleeve to Nicholas Murray Butler, 9 and 14 Nov. 1921. 
and the American Association of University Women, than with various professional associations for deans. Indeed, Gildersleeve's initiative in the Seven Sisters Conference firmly anchored Barnard's leadership among the eastern women's colleges.

Gildersleeve believed that women's single-sex education was as valuable as all-male collegiate education but under-appreciated and under-financed. Together with the presidents of the other Seven Sisters, Gildersleeve wrote an article for the November 1927 issue of the Atlantic Monthly in order "to create greater public awareness of the service being performed for the whole country by our colleges, and the peculiar financial difficulties under which they work." 100 In the ensuing months, Gildersleeve, serving as the organization's secretary, played an increasingly prominent role as the group of seven administrators met several times in the first year at Manhattan's Cosmopolitan Club to plan strategy. The college heads sponsored a media campaign and a series of dinners and consulted with trust officers and representatives of the newly formed philanthropic departments in banks, foundation officers, lawyers, and publishers. When overtures to two of the most prominent benefactors in the U.S.-John D. Rockefeller and Edson Ford-proved unsuccessful, the colleges targeted their appeal of "bricks without straw" to individual donors. Their goal was to raise scholarship funds for middle-class students. ${ }^{101}$ In 1932, against the backdrop of the Great Depression, the colleges formed an Advisory Group of prominent men-the businessman Bernard Beruch, the financier Thomas Lamont, the jurist Charles Evan Hughes, and the politician Newton D. Lawrence, among them. The Advisory Group's report, an "estimate of the contribution of the women's colleges to the culture of America,"102 became a "textbook" for fund-raising and was meant to underscore within the public mind that the Seven Sisters "stand to the education of women as the universities stand to that of men."103

The financial crisis of the 1930s impeded fund-raising efforts but the basis for continued consultation among Barnard and the other Seven Sisters, in terms of benchmarking campus and

100. Gildersleeve to William A. Neilson, 20 May 1926, Office of the President, William Neilson, Smith College Archives, Northampton, Massachusetts (hereafter cited WNSCA). The article appeared as anticipated: see Virginia Crocheron Gildersleeve et al. Atlantic Monthly 140 (Nov. 1927): 576-84.

101. See NY Times Sunday Magazine, 6 May 1928.

102. WNSCA, "Report of the Alumnae Committee of Seven Colleges,” May 1933.

103. WNSCA, Maude Stewart to William Allan Neilson, 19 Mar. 1932. 
academic policies and, with the advent of World War II, developing campus initiatives to support the war effort, went on. At Barnard, Gildersleeve devoted faculty resources and classroom space to Columbia's efforts to provide training for young midshipmen, but she emphasized firmly to young women, many of whom considered leaving schools to support families or to work in the war-related industries, that their most patriotic service would be to complete their college degrees. Retiring in 1947, Virginia Gildersleeve during her long tenure put her mark on Barnard College no less than Nicholas Murray Butler had left his on Columbia University.

\section{Conclusion}

The women who held the deanship during Barnard's first halfcentury nurtured and institutionalized the idea that had been at the heart of the College's founding: women needed a full-fledged liberal arts education, comparable to men's, to unleash and demonstrate their full intellectual potential. As I have shown, these deans were able to strengthen their position and to institutionalize the idea behind the establishment of Barnard College. Inspired by Barnard's founding mission and building upon the achievements of her predecessors, each dean contributed to furthering Barnard's collegiate standing by elevating academic standards, securing the funds for needed campus building, and articulating the need for women's liberal arts education.

Acting more like presidents of independent women's colleges, Barnard's successive female deans guided Barnard's growth from a local annex - a financially struggling day school that was subordinate in every respect to Columbia-into a leading female institution whose vision of women's liberal arts education and dynamic campus life capitalized upon and participated in the making of the Columbia milieu. Beyond that, the Barnard deans, demonstrating concerns similar to those of deans of women in coeducational institutions, proceeded to open up opportunities for women throughout the university-becoming a voice for women across campus divisions. Indeed, the Barnard deans were institution-builders not only of Barnard but also of Columbia University.

The stories of Barnard's deans provide an answer to the question that prefaced this article concerning the nature of female leadership: “Are deans like poets or can they be made?" These 
women, though accomplished, were not trained for their decanal responsibilities. ${ }^{104}$ Rather, their leadership and the range and impact of their contributions at Barnard and Columbia were shaped by their sensibilities as educated women and developed in response to circumstances and challenges they encountered. Indeed, in their own way, like national "poets," the Barnard deans were not made but rose to meet the challenge of their moment. They had historical insights into the aspirations of earlier generations of women who had hungered for justice and equity in education; they were conscious of women's contemporary status in the academy and society at large; and, mindful of the lessons of both past and present, they were able to build a top-calibre college for women. Their combined efforts wove a legacy of female leadership that might raise the aspirations of future generations of women. And it was this legacy, carried forth by later deans and faculty, that was instrumental in giving Barnard in 1983 the determination to retain its autonomy and re-kindle its commitment to women's education when Columbia demanded that the two institutions should merge. ${ }^{105}$

104. All the deans considered here built their careers before the rise of professional training for deans. See note 4.

105. Unlike its peer co-ordinates Radcliffe and Pembroke, Barnard withstood the pressure to merge with its host university during the push toward co-education in the late 1960s through the early 1980s. Whereas many single-sex liberal arts colleges had to merge or close because of the social and fiscal challenges of this period, Barnard questioned whether co-education would bring equity. 